\title{
The Treatment of Pernicious Anemia in Children with Graves' Disease
}

\author{
Jung Kyung Yoo, M.D., \\ Seung Yang, M.D., \\ Young Seok Shim, M.D. \\ and Joon Sup Song, M.D.
}

Department of Pediatrics, Hallym University College of Medicine, Seoul, Korea
Received: 31 May, 2012

Revised: 15 June, 2012

Accepted: 19 June, 2012

Address for correspondence: Joon Sup Song, M.D.

Department of Pediatrics, Hallym University Kangdong Sacred Heart Hospital, 150 Seongan-ro, Gangdong-gu, Seoul 134-701, Korea

Tel: +82.2-2224-2251

Fax: $+82.2-482-8334$

E-mail: pedsjs@hallym.or.kr
Organ specific autoimmune diseases may occur in the same individual. Type III polyglandular autoimmune disease is defined by the occurrence in the same individual of two or more of the following: autoimmune thyroid disease, pernicious anemia, insulin dependent diabetes, and other organ specific autoimmune diseases not falling into class I or class II categories.

A 16-year-old girl developed pernicious anemia during the treatment of Graves' disease. She was diagnosed with Graves' disease 5 years ago and had received methimazole $20 \mathrm{mg} /$ day, but the medication was not well tolerated. Bone marrow findings were compatible with pernicious anemia as macrocytic normochromic red blood cell (RBC) and increased megakaryocyte. The serum value of vitamin $B_{12}$ was low, and the serum titer of antibody to gastric parietal cell was high. After diagnosis of pernicious anemia, she had treatment by monthly intramuscular vitamin $B_{12}$ and methimazole ( $20 \mathrm{mg} /$ day). The values of hemoglobin and RBC indices as well as thyroid function were normalized after 2 months. Vitamin $B_{12}$ therapy was maintained for 1 year with normal RBC indices. At present, she dose not receive treatment with vitamin $B_{12}$ but she does receive methimazole treatment.

We report a case of treatment of pernicious anemia in a 16 year-old girl during treatment for Graves disease.

Key Words: Graves disease; Anemia, pernicious

\section{Introduction}

그레이브스병은 미만성독성갑상선종이라고도 하며 소아에서 갑상선기능항진증의 $95 \%$ 이상의 원인이다. 이 질환은 갑상선 혈장막에 대한 항체에 의해 유발이 되어 갑상선 낭의 과도한 호르몬 생성을 유발하게 된다. 갑상선자극호르몬 항체가 $95 \%$ 이상에서 검 출되며 소아의 신경계 발달 및 감정조절에 영향을 준다. 그 결과 지능저하, 체중감소, 열 불내성 및 발한, 심계항진 등의 증상을 나타낸다. 여아에서 남아보다 약 5 배 많이 발생하 며 나이가 증가할수록 급격히 증가하며 청소년기에 최고에 달한다 ${ }^{1)}$.

그레이브스병과 같은 자가면역성 갑상선질환은 다인성 및 유전적 경향을 갖고 있으며, 면역조절의 결핍 및 불내성, 자가단백질인식장애에 의해 여러 임상적 양상을 보이게 된 다. 이로 인해 다른 자가면역성 질환을 동반하게 되는 경우가 많으며 1형 당뇨, 류마티스 관절염, 전신성홍반성루푸스, 쇼그렌증후군, 염증성장질환, 중증근무력증이나 악성빈 혈 등에서 동반되는 경우가 흔하게 보고된다. 연구에 따라 차이가 있지만 약 40-50\%에 서 동반되어 나타난다 ${ }^{2}$. 이러한 면역성의 변화는 표적 기관뿐만 아니라 전신적 기관에도 영향을 주게 되어 하나의 증후군으로 표현하기도 한다. 이 중 악성빈혈 또는 비타민 $\mathrm{B}_{12}$ 결핍은 자가면역성 갑상선질환을 가진 집단에서 일반 인구집단에 비해 높은 발생 빈도를 보이며, 특히 이러한 경우 갑상선 기능항진에 의한 증상 때문에 비타민 결핍 증상이 간과 
될 수 있어 주의가 필요하다 ${ }^{3)}$. 그러나 아직까지 악성빈혈이 갑상선 질환에 동반되어 발생하는 기전은 정확하지 않으며 그 치료법에 대한 보고도 국내에 거의 없다.

이에 저자들은 그레이브스병과 동반되어 발생한 연소성악 성빈혈에서 기저 질환 조절 후 빈혈 치료가 필요 없게 된 환 자 1예를 경험하였기에 보고하는 바이다.

\section{Case Report}

환 아: 16 세 여자 환자

주 소: 혈액 검사상 빈혈 소견

가족력 및 과거력: 특이 가족력 없었으며 5년 전부터 본 원에서 그레이브스병으로 진단 되어 메티마졸 $(20 \mathrm{mg} /$ 일)로 치료 중이던 환자로 치료에 대한 순응도가 낮아 지속적 갑상 선기능항진 상태였으며 내원 2년 전 빈혈 검사에서도 특이 소견은 관찰되지 않았다. 그 이후에도 동일 용량의 메티마졸 로 지속적으로 치료하였으나 이에 대한 순응도는 낮았다.

진찰소견: 신장 $158.2 \mathrm{~cm}$ (50-75 백분위수), 체중 $58 \mathrm{~kg}$ (50-75 백분위수), 체질량지수 $23.3 \mathrm{~kg} / \mathrm{m}^{2}$ (50-75 백분위 수)이었다. 혈압은 $90 / 60 \mathrm{mmHg}$, 맥박 수 80 회/분, 호흡수 20 회/분, 체온은 $36.5^{\circ} \mathrm{C}$ 이었으며 의식은 명료하였다. 경도 의 창백한 결막 소견 보였고 혀는 정상이었으며 미만성갑상 선종대가 촉지되었다. 흉부 진찰 상 특이 소견 없었으며, 복 부에서 간비종대는 관찰되지 않았다.

검사소견: 입원 시 시행한 말초혈액검사에서 백혈구 6.1 $\times 10^{9} / \mathrm{L}$, 헤모글로빈 $10.7 \mathrm{~g} / \mathrm{dL}$ (정상치 $12-16 \mathrm{~g} / \mathrm{dL}$ ), mean corpuscular volume (MCV), 108.3 fL (최저치 80 fL), mean corpuscular hemoglobin (MCH), $40.5 \mathrm{pg}$ (최저 치 $27 \mathrm{fL}$ ), 혈소판 $29.2 \times 10^{9} / \mathrm{L}$ 이었고 도말 검사에서 대적혈 구, 정색소성 빈혈 및 적혈구 부동증 소견 보였다.

혈청 검사에서 free thyroxine (fT4) $2.75 \mathrm{ng} / \mathrm{dL}$ (정상 치, $0.78-1.54 \mathrm{ng} / \mathrm{dL}$ ), triiodothyronine (T3) $247 \mathrm{ng} / \mathrm{dL}$ (정상치, 65-150 ng/dL), thyroid stimulating hormone (TSH) $0.01 \mathrm{uIU} / \mathrm{mL}$ (정상치, $0.35-5.5 \mathrm{uIU} / \mathrm{mL}$ ) 이하, anti-thyroglobulin antibody $385.9 \mathrm{U} / \mathrm{mL}$ (정상치, 0-60 $\mathrm{U} / \mathrm{mL}$ ), anti-microsome antibody $3857.3 \mathrm{U} / \mathrm{mL}$ (정상치, 0-60 U/mL), Anti-TSH receptor antibody 37.1\% (정상 치, 0-15\%) 였으며 엽산은 $7.4 \mathrm{ng} / \mathrm{mL}$ (정상치, 0.9-15.6 $\mathrm{ng} / \mathrm{mL}$ ) 로 정상, 비타민 B12는 $50 \mathrm{pg} / \mathrm{mL}$ (정상치, 225$1100 \mathrm{pg} / \mathrm{mL}$ ) 로 감소되었고 위벽세포 항체는 양성이었다.

골수 검사에서 적혈구 부동증 및 변형 적혈구 증가증을 동 반한 대적혈구 정색소성 빈혈을 보였고 철적모구는 보이지 않았다. $\mathrm{M}: \mathrm{E}$ 비율은 $1.4: 1$ 로 정상 이었고 경도의 거핵구증 다증이 관찰되었으며 거대적아구성 빈혈 소견을 보였다. 식 도 위 십이지장 내시경 검사에서는 경한 전정부 발적 이외에 는 특이 소견 보이지 않았다.

치료 및 경과: 악성빈혈 진단 후 비타민 $\mathrm{B}_{12}$ 근육주사 $(1$ $\mathrm{mg})$ 를 매달 시행하며 메티마졸 치료 $(20 \mathrm{mg} /$ 일 $)$ 도 병행하 였다. 이후 환자 순응도 또한 개선되었다. 치료 2 개월 후 시 행한 혈액 검사에서는 fT4 $1.95 \mathrm{ng} / \mathrm{dL}$ 로 감소, TSH 0.07 $\mathrm{uIU} / \mathrm{mL}$ 로 증가하며 갑상선 기능의 호전 보였고 헤모글로 빈 $14.7 \mathrm{~g} / \mathrm{dL}, \mathrm{MCV} 79.6 \mathrm{fL}, \mathrm{MCH} 26.8 \mathrm{pg}$ 으로 빈혈도 호 전되었다.

매달 메티마졸과 비타민 $\mathrm{B}_{12}$ 주사를 병행 치료한 1년 후 혈 액 검사에서 fT4 $1.16 \mathrm{ng} / \mathrm{dL}, \mathrm{TSH} 0.99 \mathrm{uIU} / \mathrm{mL}$ 로 갑상 선 기능의 호전 보였으며 백혈구 $7.7 \times 10^{9} / \mathrm{L}$, 혈소판 30.0 $\times 10^{9} / \mathrm{L}$ 및 헤모글로빈 $13.3 \mathrm{~g} / \mathrm{dL}, \mathrm{MCV} 78.2 \mathrm{fL}, \mathrm{MCH}$ $26.5 \mathrm{pg}$ 이었고 비타민 $\mathrm{B}_{12}$ 는 $384 \mathrm{pg} / \mathrm{mL}$ 로 정상이었다. 1 년 후 환자의 순응도 저하로 인해 비타민 $\mathrm{B}_{12}$ 주사치료는 중 단되었으며 메티마졸 치료는 동일 용량으로 지속되었다. 1 년 6개월 후 갑상선 기능 검사 상 fT4 $1.16 \mathrm{ng} / \mathrm{dL}$ 및 T3 99 $\mathrm{ng} / \mathrm{dL}$ 로 감소, $\mathrm{TSH} 2.76 \mathrm{uIU} / \mathrm{mL}$ 로 증가 및 anti-TSH receptor Ab 21.9\% 였고 헤모글로빈 14.2 g/dL, MCV 80.8 $\mathrm{fL}, \mathrm{MCH} 27.2 \mathrm{pg}$ 로 갑상선 기능 및 빈혈 소견 정상 범위였 으며 2년 후 검사에서도 fT4 $1.31 \mathrm{ng} / \mathrm{dL}$ 및 T3 $92 \mathrm{ng} / \mathrm{dL}$ 로 감소, TSH $3.72 \mathrm{uIU} / \mathrm{mL}$ 및 헤모글로빈 $14 \mathrm{~g} / \mathrm{dL}, \mathrm{MCV}$ $83.9 \mathrm{fL}, \mathrm{MCH} 27.9 \mathrm{pg}$ 으로 갑상선 기능 정상이었으며 빈혈 소견 없었다. 현재 환자는 1 년 가량의 비타민 $\mathrm{B}_{12}$ 치료 중단

Table 1. Laboratory results after treatment by methimazole and vitamin $B_{12}$

\begin{tabular}{|c|c|c|c|c|}
\hline & $\mathrm{fT}^{*}(\mathrm{pg} / \mathrm{dL})$ & $\mathrm{Hb}^{\dagger}(\mathrm{g} / \mathrm{dL})$ & $\mathrm{MCV}^{\ddagger}(\mathrm{fL})$ & Vitamin $B_{12}^{5}(\mathrm{pg} / \mathrm{mL})$ \\
\hline Treatment start with methimazole and vitamin $B_{12}$ & 2.26 & 10.7 & 108.3 & 50 \\
\hline After 2 mo of treatment & 1.95 & 14.7 & 79.6 & 66 \\
\hline After 6 mo of treatment & 2.16 & 14.9 & 74.3 & 72 \\
\hline After $1 \mathrm{yr}$ of treatment (discontinued vitamin $\mathrm{B}_{12}$ treatment) & 1.16 & 13.3 & 78.2 & 82 \\
\hline After 18 mo of treatment (after 6 mo of discontinued vitamin $B_{12}$ treatment ) & 1.16 & 14.2 & 80.8 & 216 \\
\hline After 2 yr of treatment (after $1 \mathrm{yr}$ of discontinued vitamin $\mathrm{B}_{12}$ treatment ) & 1.31 & 14.0 & 83.9 & 315 \\
\hline
\end{tabular}

* Free T4 (fT4), normal range: 0.78-1.54 ng/dL.

${ }^{\dagger}$ Hemoglobin $(\mathrm{Hb})$, normal range: $12-16 \mathrm{~g} / \mathrm{dL}$.

${ }^{\ddagger}$ Mean Corpuscular Volume (MCV), minimal range: $80 \mathrm{fL}$.

${ }^{5}$ Vitamin $B_{12}$, normal range: $225-1100$ pg/mL. 
후 추가 근육주사 없이 동일 용량의 메티마졸 치료만으로 빈 혈 및 비타민 $\mathrm{B}_{12}$ 결핍 보이지 않고 있다(Table 1). 그러나 위 벽세포 항체는 계속적으로 양성이다.

\section{Discussion}

자가면역질환이란 자가항체에 대한 면역 내성의 저하로 인해 발생하는 만성적 상태를 의미한다. 자가면역다선증후 군이란 장기 특이적인 자가면역 질환이 2 개 이상의 장기를 침범하여 증상을 나타내는 복잡한 질환이다. 최근 이에 대 한 임상적 중요성이 점차 증가하고 있으며 여러 종류의 자가 면역성 내분비질환의 임상양상과 동반 질환에 대한 이해가 넓어지고 있다. 자가면역다선증후군은 1922년 Schmidt ${ }^{13 .}$ ${ }^{15)}$ 에 의해 처음으로 보고되었고 부신 피질 기능부전증으로 사망한 환자에서 부신 및 갑상선에 심한 림프구 침윤과 조 직 파괴를 관찰하였으며 이를 2개의 선질환으로 보고하였 다. 그 후 여러 연구에 의해 이러한 질환의 병인에 면역 기전 이 관여한다는 사실이 밝혀져서 다선증후군은 다양한 자가 면역질환들의 복합적 증후군으로 알려지게 되었다. 이 증후 군은 동반되는 질환에 따라 3 가지 형태로 분류되며, 1 형은 주로 부갑상선 및 부신피질을 침범하며 피부 캔디다증 및 기 타 피부 자가면역질환을 나타내는 드문 질환이다 ${ }^{14)}$. 제 2형 은 자가면역성 부신염, 갑상선 질환 및 당뇨병 등으로 구성 된다. 제 3형 자가면역증후군은 일반적으로 자가면역성 갑 상선 질환을 가지고 있는 환자에서 아디손병을 제외한 기타 의 자가면역성 질환이 동반되는 경우를 말한다. 이러한 경우 악성빈혈, 인슐린의존형 당뇨병, 자가면역성 뇌하수체염, 중증근무력증, 백반증, 탈모증, 셀리악병, 자가면역성 간 염 및 기타 교원질환 등의 동반이 최근 보고되었다 ${ }^{8)}$. Ness$\mathrm{Abramof}^{2)}$ 등은 자가면역성 갑상선 질환군의 $28 \%$ 에서 낮은 비타민 $\mathrm{B}_{12}$ 농도를 보였다고 보고하였다. 이런 경우 비타민 $\mathrm{B}_{12}$ 결핍 증상이 애매할 수 있고 간과되기 쉬워, 조기에 진단 할 수 있는 도구에 대한 연구가 최근에 활발히 이루어지고 있다 ${ }^{4)}$

악성빈혈은 내인자의 결핍으로 인한 비타민 $\mathrm{B}_{12}$ 부족으로 인해 발생하는 대적혈구성 빈혈로 정의한다 ${ }^{9)}$. 위벽위축의 조직학적 소견 및 혈중 가스트린의 증가 등의 측정이 진단에 도움이 되며, Schilling test를 시행하지 않은 경우에도 내인 자 및 위벽세포 항체 양성률이 각 $73 \%$ 와 $100 \%$ 이다. 악성빈 혈을 가진 환자의 $40 \%$ 에서 자가면역성 갑상선질환이 동반 되며 ${ }^{5)}$ human leukocyte antigen (HLA)-DR 유전형이 악 성빈혈의 유전적 감수성과 관련이 있다고 알려져 있다 ${ }^{10)}$.

본 환자는 그레이브스병이 먼저 발생되고 약 5 년 후 악성 빈혈이 병발된 상태로 제 3형의 자가면역다선증후군으로 분류할 수 있다. 자가면역성 갑상선 질환을 가진 환자의 약
$1 / 3$ 에서는 위벽세포 항체가 검출되며 악성빈혈의 발생 빈도 가 높은 것으로 알려지고 있다 ${ }^{12)}$. 이 두 질환이 서로 병발되 는 이유는 갑상선과 위벽세포가 모두 전장(foregut) 에서 유 래함으로써 면역 결정기를 공유할 가능성이 높기 때문이다. 이 환자에서의 악성빈혈은 일반적 악성빈혈과 달리 자가면 역성 갑상선질환에 동반되어 발생하였으며, 검출된 위벽세 포항체가 악성빈혈의 표식자로서의 의의를 갖는다고 생각 된다.

자가면역다선증후군에서 기저 질환에 대한 치료가 동반된 자가면역질환의 경과에 영향을 준다는 보고는 많지 않으나, 최근 자가면역성 갑상선질환에 동반된 에반증후군의 경우 스테로이드 치료 없이 기저 갑상선질환 치료 후 호전을 보였 다는 1 례가 보고되었다. 반면에 악성빈혈에 대한 치료 자체 가 동반된 갑상선질환에서 갑상선 기능 호전에는 큰 영향을 주지 못하였다는 보고도 있다 ${ }^{7}$. 그러나 자가면역성 갑상선 질환과 동반된 악성빈혈의 치료에 대해서는 아직 많이 보고 되지 않았으며 특히 국내에서는 아직까지 보고되지 않았다.

본 증례에서 위벽세포항체는 계속적으로 양성이나 기저질 환인 그레이브스병이 조절되면서, 비타민 $\mathrm{B}_{12}$ 결핍에 의한 악성빈혈은 비타민 $\mathrm{B}_{12}$ 근육주사가 중단되었음에도 불구하 고 치료가 되었다. 이와 같이 자가면역다선증후군에서 기저 질환의 치료는 동반된 다른 질환도 치료될 수 있음을 본 예 를 통해 알 수 있었다. 하지만 지속적인 추적관찰을 통해 위 벽세포항체의 소실 유무를 확인해야 할 것으로 사료된다.

이에 저자들은 그레이브스병에 동반되어 발생한 악성빈혈 에서 그레이브스병의 치료 후 동반된 질환의 치료가 필요 없 게 된 1례를 보고하는 바이다.

\section{References}

1) Shawn D. Safford, Michael A. Skinner. Thyroid and parathyroid disease in children.Semin Pediatr Surg 2006;15:85-91.

2) Lapcevi M. Autoimmune thyroid disease and associated diseases.Srp Arh Celok Lek 2005;133 Suppl 1:84-7.

3) Ness-Abramof R, Nabriski DA, Braverman LE, Shilo L, Weiss E, Reshef T, et al. Prevalence and evaluation of Vit B12 deficiency in patients with autoimmune thyroid disease.Am J Med Sci 2006;332:119-22.

4) Centanni M, Marignani M, Gargano L, Corleto VD, Casini A, Delle Fave G, et al. Atrophic body gastritis in patients with autoimmune thyroid disease: an underdiagnosed association. Arch Intern Med 1999;159:1726-30.

5) Lombardo F, Messina MF, Salzano G, Rabbone I, Lo Presti $\mathrm{D}$, Calcaterra V, et al. Prevalence, presentation and clinical evolution of Graves' disease in children and adolescents with type 1 diabetes mellitus. Horm Res Paediatr 2011;76:221-5. 
6) Djurica S, Trbojevi B, Milosevi DP, Markovi N. Autoimmune thyroid disease, clinical symptoms of associated autoimmunity. Srp Arh Celok Lek 2005;133 Suppl 1:16-24.

7) Todd A, Todd J. Graves' disease following successful treatment of severe aplastic anaemia with antilymphocyte globulin. Clin Lab Haematol 1999;21:69-70.

8) Dilas LT, Icin T, Paro JN, Bajkin I. Autoimmune thyroid disease and other non-endocrine autoimmune diseases. Med Pregl 2011;64:183-7.

9) Lahner E, Annibale B. Pernicious anemia: new insights from a gastroenterological point of view. World J Gastroenterol 2009;15:5121-8.

10) Cho WK, Jung MH, Choi EJ, Choi HB, Kim TG, Suh BK. Association of HLA alleles with autoimmune thyroid disease in Korean children. Horm Res Paediatr 2011;76:32834 .
11) Oh HJ, Yun MJ, Lee ST, Lee SJ, Oh SY, Sohn I. Evans syndrome following long-standing Hashimoto's thyroiditis and successful treatment with rituximab. Korean J Hematol 2011;46:279-82.

12) Erslev AJ, Williams WJ. Anemia of endocrine disorders. Hematology. 4th ed. New York: McGraw Hill; 1990.

13) Schmidt MB. Eine bigladulare erkankung: nebenieren und schildruse bei morbis addisoni. Dtsch Ges Pathol 1926;21:212-21.

14) Carmel R, Spencer CA. Clinical and subclinical thyroid disorders associated with pernicious anemia. Observations on abnormal thyroid-stimulating hormone levels and on a possible association of blood group $\mathrm{O}$ with hyperthyroidism. Arch Intern Med 1982;142:1465-9.

15) Ho-Young Son. Polyglandular autoimmune syndrome. Endocrinol Metab 1987;2:131-5.

\section{그레이브스병과 동반되어 발생한 연소성 악성빈혈의 치료 1례}

\section{유정경·양 승· 심영석· 송준섭}

한림대학교 의과대학 소아과학교실

갑상선 질환을 비롯한 자가면역성 질환은 다인성 및 유전적 경향을 띠고 있으며 HLA-DR과 관련이 있다고 알려져 있 다. 다른 자가면역성 질환을 동반하는 경우가 흔하며 1형 당뇨, 류마티스 관절염, 전신성홍반성루푸스, 쇼그렌증후군, 염증성 장질환, 중증근무력증이나 악성빈혈, 백반증, 셀리악병, 자가면역성 간염 및 원형탈모증과 동반되는 경우가 보 고되어 있다. 5년 전 그레이브스병 진단 후 메티마졸을 복용하였으나 순응도가 높지 않아 치료가 부진하였던 16세 환 자에서 악성빈혈이 동반되어 발생하였다. 환자는 비타민 $\mathrm{B}_{12}$ 근육주사와 메티마졸 병행치료 후 악성빈혈 소견 호전되 었고 정상적인 갑상선 기능을 보였다. 현재 환자는 비타민 $\mathrm{B}_{12}$ 치료를 중단한 후 메티마졸 치료로 외래에서 경과 관찰 중이다. 저자들은 그레이브스병과 동반되어 발생한 연소성 악성빈혈에서 기저 질환 조절 후 약물 치료가 필요 없게 된 환자 1 례를 경험하였기에 문헌 고찰과 함께 보고하는 바이다. 